Article

\title{
Chemical Composition and In Vitro Antioxidant and Antimicrobial Activities of the Marine Cyanolichen Lichina pygmaea Volatile Compounds
}

\author{
Hiba Sanad ${ }^{1}$, Zahira Belattmania 1(D, Ahmed Nafis ${ }^{2}$, Meryem Hassouani ${ }^{1,3}$, Noureddine Mazoir ${ }^{1}$, \\ Abdeltif Reani ${ }^{1}$, Lahcen Hassani ${ }^{4}$, Vitor Vasconcelos ${ }^{3,5, *(\mathbb{D})}$ and Brahim Sabour ${ }^{1}$ (D)
}

1 Laboratory of Plant Biotechnology, Ecology and Ecosystem Valorization-URL CNRST $\mathrm{N}^{\circ} 10$, Faculty of Sciences El Jadida, University Chouaib Doukkali, P.O. Box 20, El Jadida 24000, Morocco; hiba.sanad.ucd@gmail.com (H.S.); belattmania.z@ucd.ac.ma (Z.B.); m.hassouani@gmail.com (M.H.); mazoirn@gmail.com (N.M.); abreani@yahoo.fr (A.R.); sabour.b@ucd.ac.ma (B.S.)

2 Department of Biology, Faculty of Sciences El Jadida, University Chouaib Doukkali, P.O. Box 20, El Jadida 24000, Morocco; ahmed.nafis@edu.uca.ac.ma

3 CIIMAR, Interdisciplinary Centre of Marine and Environmental Research, University of Porto, Terminal de Cruzeiros do Porto de Leixões, Av. General Norton de Matos, s/n, 4450-208 Matosinhos, Portugal

4 Laboratory of Microbial Biotechnologies, Agrosciences and Environment, Faculty of Sciences Semlalia, University Cadi Ayyad, P.O. Box 2390, Marrakech 40001, Morocco; lhassani@uca.ac.ma

5 Department of Biology, Faculty of Sciences, University of Porto, Rua do Campo Alegre, 4169-007 Porto, Portugal

* Correspondence: vmvascon@fc.up.pt; Tel.: +351-223-401-817

Citation: Sanad, H.; Belattmania, Z.; Nafis, A.; Hassouani, M.; Mazoir, N.; Reani, A.; Hassani, L.; Vasconcelos, V.; Sabour, B. Chemical Composition and In Vitro Antioxidant and Antimicrobial Activities of the Marine Cyanolichen Lichina pygmaea Volatile Compounds. Mar. Drugs 2022, 20, 169. https://doi.org/ $10.3390 / \mathrm{md} 20030169$

Academic Editors: Philippe Michaud and Igor Jerković

Received: 10 January 2022

Accepted: 23 February 2022

Published: 25 February 2022

Publisher's Note: MDPI stays neutral with regard to jurisdictional claims in published maps and institutional affiliations.

Copyright: () 2022 by the authors. Licensee MDPI, Basel, Switzerland. This article is an open access article distributed under the terms and conditions of the Creative Commons Attribution (CC BY) license (https:// creativecommons.org/licenses/by/ $4.0 /)$.

\begin{abstract}
Volatile compounds from the marine cyanolichen Lichina pygmaea, collected from the Moroccan Atlantic coast, were extracted by hydrodistillation and their putative chemical composition was investigated by gas chromatography coupled to mass spectrometry (GC/MS). Based on the obtained results, Lichina pygmaea volatile compounds (LPVCs) were mainly dominated by sesquiterpenes compounds, where $\gamma$-himachalene, $\beta$-himachalene, $(2 E, 4 E)-2,4$ decadienal and $\alpha$-himachalene were assumed to be the most abundant constituents, with percentage of $37.51 \%, 11.71 \%, 8.59 \%$ and $7.62 \%$, respectively. LPVCs depicted significant antimicrobial activity against all tested strains (Staphylococcus aureus CCMM B3, Pseudomonas aeruginosa DSM 50090, Escherichia coli ATCC 8739 and Candida albicans CCMM-L4) with minimum inhibitory concentration (MIC) values within the range of $1.69-13.5 \mathrm{mg} / \mathrm{mL}$. Moreover, this LPVC showed interesting scavenging effects on the 2,2-diphenyl-1-picrylhydrazyl radical with an $\mathrm{IC}_{50}$ of $0.21 \mathrm{mg} / \mathrm{mL}$. LPVCs could be an approving resource with moderate antimicrobial potential and interesting antioxidant activity for cosmetics and pharmaceutical applications.
\end{abstract}

Keywords: volatile compounds; Lichina pygmaea; chemical composition; antioxidant and antimicrobial activities

\section{Introduction}

Lichens, as symbiotic complex of autotrophic (microalgae, cyanobacteria) and heterotrophic (fungi), are highly adapted to extreme habitats comprising the coastal zones [1]. Indeed, marine lichens are exposed to an exceptionally range of pressures, due to daily tidal cycles that terrestrial lichens cannot resist [2]. The lichens growing on littoral and supralittoral zones differ in their resistance to the duration of exposure to salt water and are clearly distinguished taxonomically [1]. Some studies determined lichen zones without connecting them to tidal cycles [3], and others highlighted the significance of tidal periodicity [4-6]. Species of the genus Lichina are attractive marine lichens due to their outstanding habitat, commonly colonized by a relatively limited number of pyrenocarpous lichens (frequently crustose). Lichina is the only shrubby lichen and is associated with cyanobacterial photobionts, allowing both acquisition of inorganic carbon and nitrogen 
fixation [7]. The closely related marine Lichina species (L. confinis and L. pygmaea) have comparable distribution ranges in the Northeast Atlantic, usually co-occurring at the same rocky coast but inhabiting different littoral zones [8]. According to Smith, [9], L. confinis could reach higher latitudes (Norway and Iceland), whereas L. pygmaea could be found at lower latitudes (Morocco and Canary Islands).

L. pygmaea (Lightf.) C. Agardh is a saxicolous fruticose lichen that occupies the upper intertidal zone, forming dark cushions some millimeters thick (Figure 1). It was historically considered to form a symbiosis with Calothrix [10], updated, afterwards, via molecular characterization to Rivularia [8]. L. pygmaea undergoes harmful UV radiation, exposure to sun and reverberation, salty conditions, immersion times, and wave actions. Consequently, this lichen could possess protective secondary metabolites with bioactive properties [11]. The majority of secondary metabolites in lichens are produced through the polyketide pathway and consist mainly of monocyclic phenols and bicyclic phenols attached by an ester bond [12]. Several lichens have been confirmed to be a source of important secondary metabolites for pharmaceutical applications [13]. There is growing interest in the pharmaceutical properties of compounds derived from lichens. However, fairly few lichen substances have been deeply monitored for biological activity and therapeutic potential; this is mainly due to the difficulties of having them in high quantities and adequate purities for structural elucidation and pharmacological tests [11]. It has been previously reported that lichen secondary metabolites exhibit antimicrobial, antioxidant, anti-inflammatory, cytotoxic, analgesic, antipyretic, and antiviral properties and could be potential sources of pharmaceutically useful chemicals [11]. In this context, the present study aims to evaluate, for the first time, the antioxidant and antimicrobial activities of volatile compounds of Lichina pygmaea harvested from the Moroccan Atlantic coast.

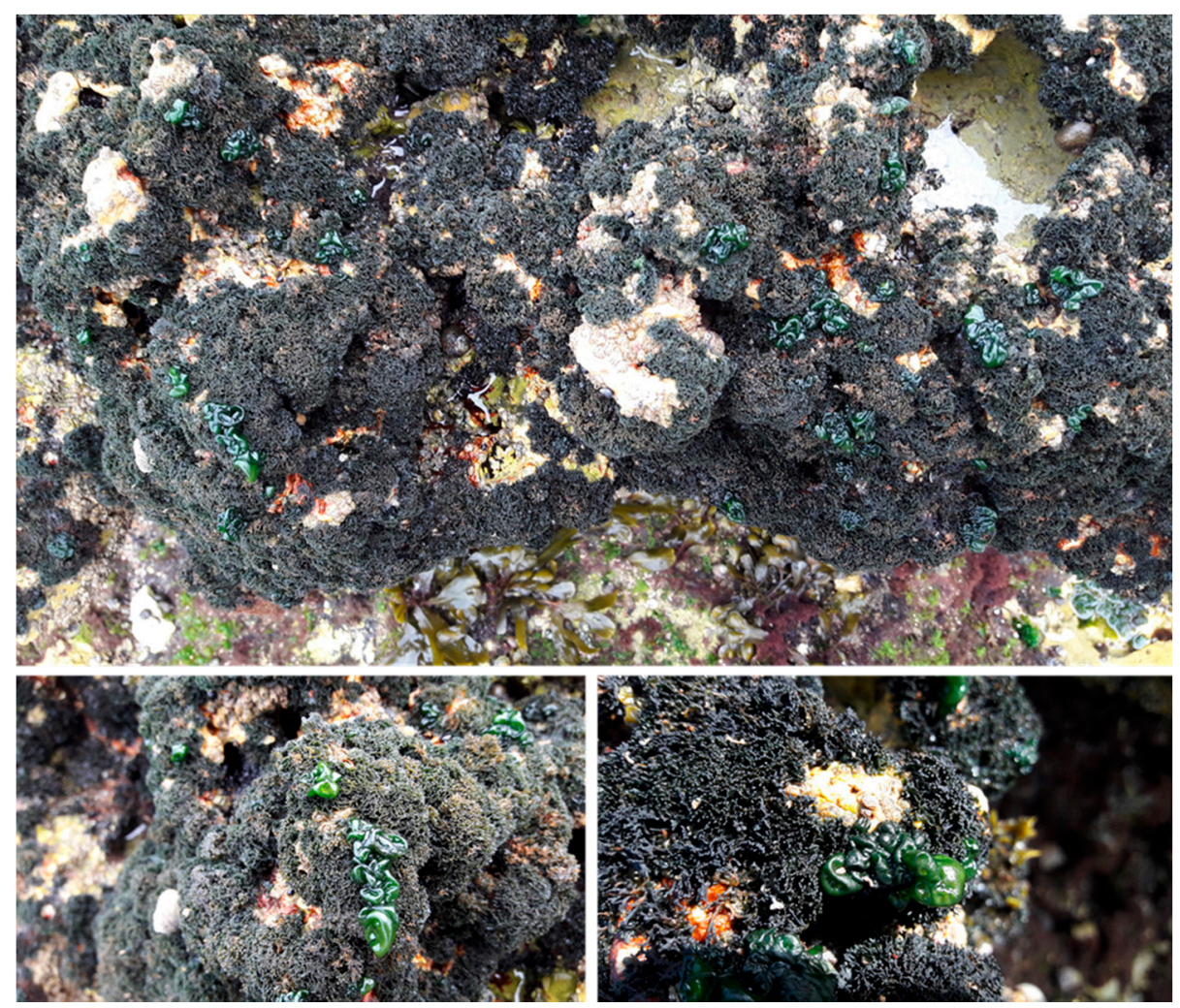

Figure 1. Photos of Lichina pygmaea epiphytized by flourished vesicles of its cyanobiont Rivularia bullata. 


\section{Results and Discussion}

\subsection{Chemical Composition of the Volatile Compounds}

The chemical components of Lichina pygmaea volatile compounds (LPVCs) were determined by GC/MS (Figure 2). In total, 25 volatile organic constituents were presumed (Table 1), which represent $93.54 \%$ of total volatile compounds (VCs). Sesquiterpenes, the major class of compounds, and $\gamma$-himachalene, $\beta$-himachalene, $(2 E, 4 E)$-2,4-decadienal and $\alpha$-himachalene seem to be the most abundant compounds, with percentages of $37.51 \%$, $11.71 \%, 8.59 \%$ and $7.62 \%$, respectively. Compared to the literature, LPVCs exhibit a special chemical composition in terms of volatile compounds. Kahriman et al. [14] showed that Evernia prunastri and Evernia divaricata EOs were characterized by monoterpene hydrocarbons (23.3 and 37.7\%) and oxygenated monoterpenes (7 and 13.0\%) as major constituents in the EO, respectively. Moreover, these compounds were $\beta$-pinene $(6.3 \%$ and $8.0 \%)$, $\alpha$-pinene $(6.6 \%, 7.2 \%)$, limonene $(1.6 \%, 6.3 \%), \alpha$-phellandrene $(3.3 \%, 4.4 \%)$, respectively. Furthermore, Maqbul et al. [15] demonstrated that amino acid (38.1\%) and cymene $(29.1 \%)$ were the most volatile constituents in the lichen Parmotrema perlatum EO. The sesquiterpene $(E, E)$ 2,4-decadienal present in LPVCs could be related to the associated cyanobiont, Rivularia bullata. This polyunsaturated aldehyde, usually reported in Diatoms microalgae [16], has also been identified in the Cyanobacteria Anabaena and Microcystis [17]. From the obtained results, it is obvious that VCs profile of L. pygmaea as marine lichen is significantly different from some previously investigated terrestrial lichens. The volatile organic compounds in marine macrophytes, released into the seawater, are implicated in the chemical communications process; these compounds have a vital role as pheromones or allelochemicals for communication and interaction with the surrounding environment $[18,19]$. The marine macrophytes species generate the volatile organic compounds depending to their physiology and ecosystem abiotic stresses [20].

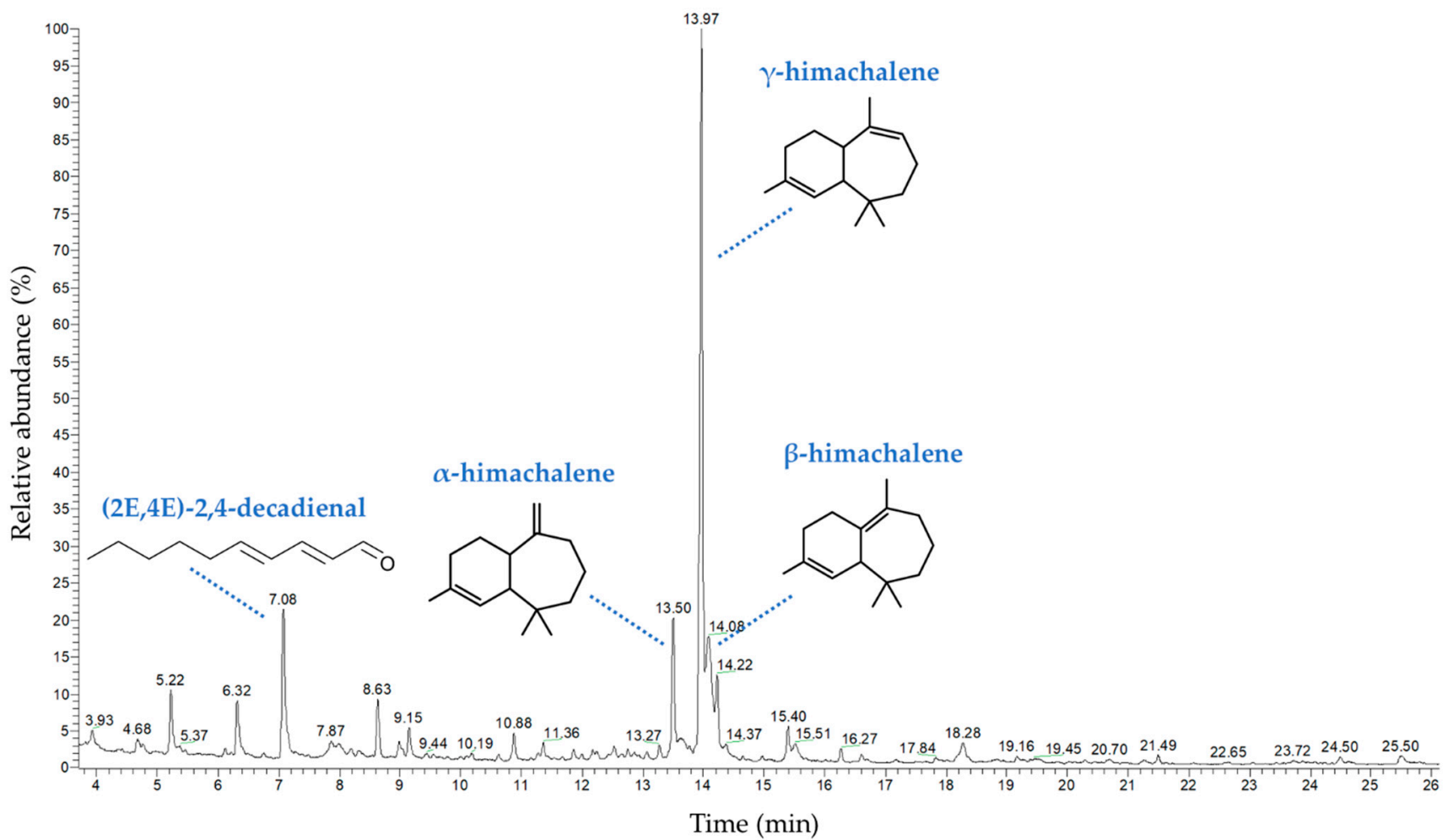

Figure 2. GC/MS chromatogram of Lichina pygmaea volatile compounds with putative chemical structures of the most abundant molecules. 
Table 1. Chemical composition of volatile constituents extracted from Lichina pygmaea.

\begin{tabular}{|c|c|c|}
\hline RI & Coumpound Name & Relative Abundance (\%) \\
\hline 769 & 2,3-dibutyloxirane & 1.14 \\
\hline 1258 & 1-decanol & 0.76 \\
\hline 1250 & (Z)-2-decenal & 3.13 \\
\hline 1261 & (E)-2-decenal & 0.3 \\
\hline 1311 & $(E, E)$-2,4-decadienal & 4.1 \\
\hline 1314 & $(2 E, 4 E)-2,4$-decadienal & 8.59 \\
\hline 1315 & (E)-2-pentenol & 0.35 \\
\hline 1350 & limonene oxide & 0.43 \\
\hline 1364 & 2-undecenal & 2.71 \\
\hline 1380 & (E)-4,5-epoxy-2-decenal & 2.3 \\
\hline 1469 & $\alpha$-longipinene & 0.31 \\
\hline 1473 & $\varsigma$-muurolene & 0.31 \\
\hline 1478 & $E$ - $\beta$-farnesene & 1.45 \\
\hline 1484 & 1-methyl-4-(6-methylheptan-2-yl)benzene & 0.93 \\
\hline 1490 & 4,5-di-epi-aristolochene & 0.36 \\
\hline 1506 & $(R)$-cuparene & 0.61 \\
\hline 1663 & $\alpha$-himachalene & 7.62 \\
\hline 1708 & $\gamma$-himachalene & 37.51 \\
\hline 1723 & $\beta$-himachalene & 11.71 \\
\hline 1730 & 1,3,5-himachalatriene & 3.25 \\
\hline 1735 & naphthalene & 1.77 \\
\hline 1770 & guaiazulene & 1.26 \\
\hline 1986 & caryophyllene oxide & 0.35 \\
\hline 2233 & cadalene & 1.72 \\
\hline \multirow[t]{2}{*}{2913} & n-hexadecanoic acid & 0.57 \\
\hline & Total & 93.54 \\
\hline
\end{tabular}

\subsection{Antioxidant Activity}

The antioxidant potential of LPVCs compared to BHT was tested by DPPH radical scavenging assay (Figure 3). The LPVCs and BHT depicted radical scavenging inhibition of 65.58 and $71.12 \%$ at $0.29 \mathrm{mg} / \mathrm{mL}$, respectively. The $\mathrm{IC}_{50}$ of the LPVCs $(0.21 \mathrm{mg} / \mathrm{mL})$ was relatively higher than that of the BHT $(0.08 \mathrm{mg} / \mathrm{mL})$. As shown in Figure 3, there was a positive correlation between DPPH radical scavenging activity and the concentration of the LPVC. Similar results have been reported for volatile compounds from some marine macrophytes [21]. Several studies were conducted on the antioxydant activities of Lichina extracts $[22,23]$ but reports pointing to the antioxidant activity of its volatile compounds are lacking. The radical-scavenging ability is mainly related to the hydrogen atom providing capability of a compound and is not linked to the redox potentials alone [24]. The interesting antioxidant activity of LPVCs could be due to the presence of the sesquiterpene $\gamma$-himachalene and $\beta$-himachalene [25]. The minor components may also contribute to the activity of VC individually and/or synergistically $[26,27]$. Thus, the antioxidant activity of LPVCs could be attributed to the presence of $\alpha$-longipinene and caryophyllene [28,29]. 


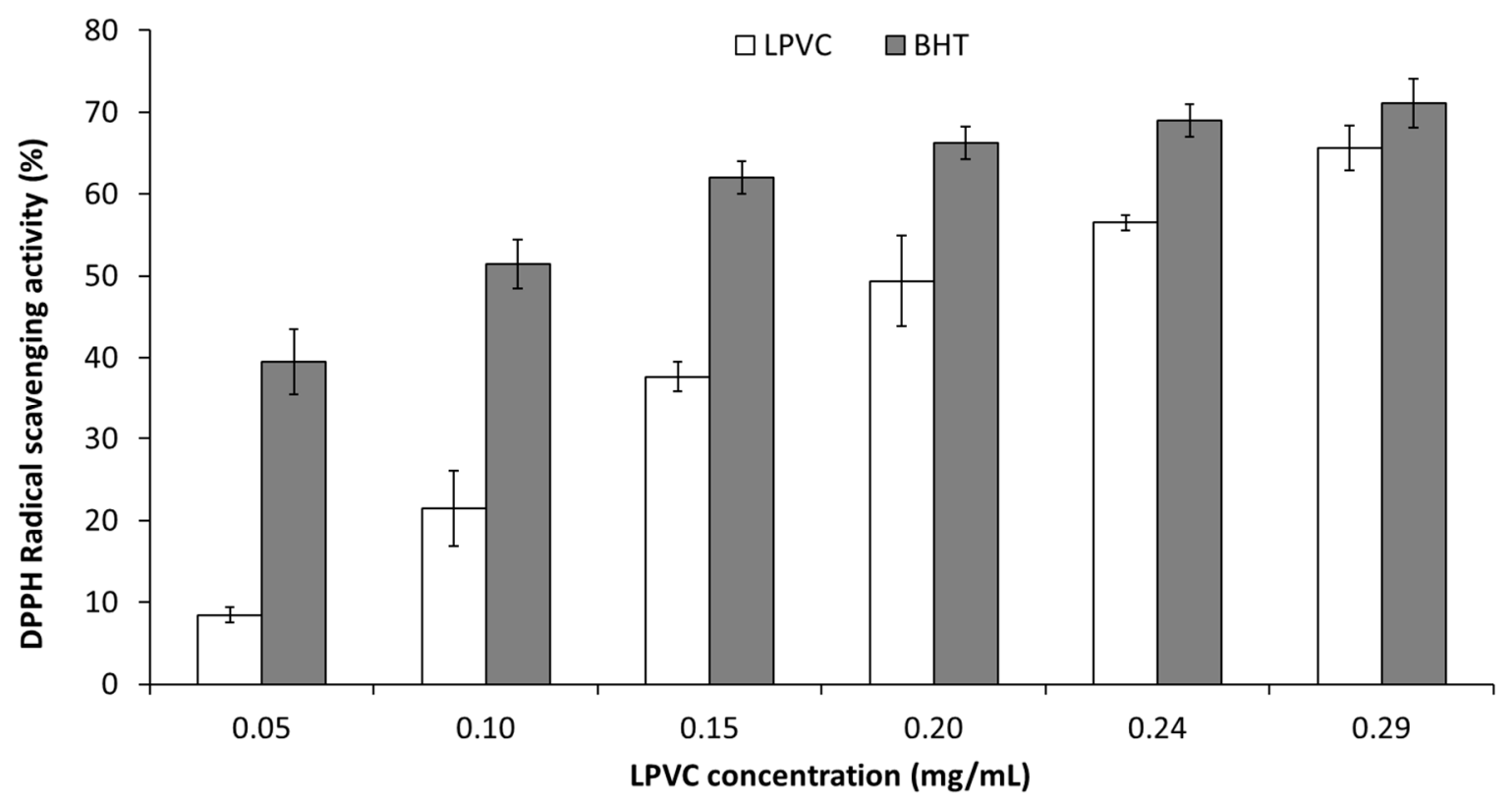

Figure 3. DPPH radical-scavenging activity of volatile compounds of Lichina pygmaea (LPVCs) compared to BHT.

\subsection{Antimicrobial Activity}

Lichina pygmaea volatile compounds were screened for their antibacterial and antifungal activities using a diffusion disc method and a microdillution on microplates assay. Based on inhibition zones, the LPVCs showed potent antimicrobial activity towards all tested microorganisms, with hallo diameters ranging from $9.5 \mathrm{~mm}$ to $16 \mathrm{~mm}$ (Table 2). The highest zones were observed against Candida albicans (CCMM-L4) and Staphylococcus aureus (CCMM B3), with $16 \mathrm{~mm}$ and $14 \mathrm{~mm}$, respectively. However, the lowest one was recorded for Escherichia coli (ATCC 8739), which was $9.5 \mathrm{~mm}$ as diameter. In addition, the antimicrobial efficiency of LPVCs was determined by measuring the minimum inhibitory concentration (MIC), as shown in Table 2. Particularly, a moderate antimicrobial activity was demonstrated against the Gram-negative bacteria E. coli with an MIC value of $1.69 \mathrm{mg} / \mathrm{mL}$. The other tested strains exhibited similar MIC values of $13.5 \mathrm{mg} / \mathrm{mL}$. Similarly, Maqbul et al. [15] reported that the clinical strains of Escherichia and Pseudomonas show promising susceptibility towards the Parmotrema perlatum EO. Previous studies suggested that the high resistance of Pseudomonas species was due to their capability to form biofilm, which is a physical barrier formed by exopolymeric substances [30]. In the literature, the Gram-negative bacteria were known for their resistance to the bioactive substances through the expression of certain enzymes inactivating antimicrobials or by non-enzymatic pathways such as the expression of genes responsible for efflux pumps and increased permeability or modifications of targets [31]. For the yeast $C$. albicans, their prolonged exposure to antifungals can promote the development of such tolerance and resistance by several mechanisms, including the formation of biofilms that decrease the accessibility of the antifungal, the selection of spontaneous mutations that increase the expression or decrease the sensitivity of the target and the ability to evade the host's immune system [32]. Generally, volatile compounds from marine macrophytes act as chemical defenses against bacterial and fungal biofilms [33]. In another study, methanolic and ethyl acetate extracts from the lichen Umbilicaria cylindrica demonstrated important antimicrobial activity against eight strains, including S. aureus, E. coli and C. albicans, with MIC values ranging from 15.62 to $62.50 \mu \mathrm{g} / \mathrm{mL}$ [34]. Other reports indicated that extracts from the two lichens Evernia prunastri and Pseudevernia furfuracea exhibited a higher antibacterial effect vs. five clinical isolates of methicillin-resistant S. aureus, with MIC values of 0.039 to $0.15 \mathrm{mg} / \mathrm{mL}$, and extracts of Ramalina farinacea possessed MIC values in the range of $0.078-0.625 \mathrm{mg} / \mathrm{mL}$ [35]. The antimicrobial effect of LPVC could be explained by the presence of a high level of the 
sesquiterpene himachalene derivatives, since a positive correlation between these compounds and the antimicrobial activity was proved [36]. These sesquiterpenes were very common in volatile compounds, especially those extracted from Capsicum chinense, Cedrus atlantica and Cedrus libani [37-39]. The antimicrobial activity could also be attributed to the presence of some lichen minor components. For example, caryophyllene oxide was known to possess interesting pharmacological properties such as antimicrobial and antioxidant activities [40-42]. Hence, we could confirm that LPVC is a potent weapon to fight multidrug-resistant and pathogenic strains.

Table 2. Inhibition zone diameters and MIC of Lichina pygmaea volatile compounds.

\begin{tabular}{|c|c|c|c|c|}
\hline & \multicolumn{2}{|c|}{$\begin{array}{c}\text { Lichina pygmaea } \\
\text { Volatile Compounds }\end{array}$} & \multirow[t]{2}{*}{$\begin{array}{c}\text { MIC } \\
\text { Ciprofloxacine }\end{array}$} & \multirow[t]{2}{*}{$\begin{array}{c}\text { MIC } \\
\text { Fluconazol }\end{array}$} \\
\hline & $\mathrm{IZ}$ & MIC & & \\
\hline $\begin{array}{l}\text { Gram positive bacteria } \\
\text { S. aureus(CCMM B3) }\end{array}$ & $14.0 \pm 0.33$ & $13.5 \pm 0.00$ & $0.01 \pm 0.00$ & - \\
\hline $\begin{array}{l}\text { Gram negative bacteria } \\
\text { E. coli (ATCC 8739) } \\
\text { P. aeruginosa (DSM 50090) }\end{array}$ & $\begin{array}{c}9.5 \pm 0.26 \\
11.0 \pm 0.78\end{array}$ & $\begin{array}{l}1.69 \pm 0.00 \\
13.5 \pm 0.00\end{array}$ & $\begin{array}{l}0.06 \pm 0.00 \\
0.25 \pm 0.00\end{array}$ & - \\
\hline $\begin{array}{l}\text { Pathognic yeast } \\
\text { C. albicans (CCMM-L4) }\end{array}$ & $16.0 \pm 0.24$ & $13.5 \pm 0.00$ & - & $1 \pm 0.00$ \\
\hline
\end{tabular}

IZ: Diameter of inhibition zone including disc diameter of $6 \mathrm{~mm}$, by the agar disc diffusion method at a concentration of $20 \mu \mathrm{L}$ of $\mathrm{VC} /$ disc and a concentration of $10 \mu \mathrm{g} /$ disc and $5 \mu \mathrm{g} /$ disc for fluconazol and ciprofloxacin, respectively. MIC: minimum inhibitory concentration in $\mathrm{mg} / \mathrm{mL}$.

\section{Materials and Methods}

\subsection{Sampling and Volatile Compunds Extraction}

Lichina pygmaea was collected in April 2021 at the upper midlittoral zone of the rocky shores of El Jadida ( $33^{\circ} 13^{\prime} 55.8^{\prime \prime} \mathrm{N} 8^{\circ} 33^{\prime} 24.8^{\prime \prime}$ W), Atlantic coast of Morocco. The harvested lichen was washed with water and then drained for $24 \mathrm{~h}$. The lichen biomass (100 g) was put into the glass container of hydrodistillation equipment, including $1 \mathrm{~L}$ of distilled water. The distillate was further mixed with dichloromethane solvent in a separating funnel, shaken vigorously for $20 \mathrm{~min}$ and then held until the two layers settled completely. After $2 \mathrm{~h}$, the lower layer of the separating funnel with VC was collected and concentrated using a rotary evaporator. The extracted $\mathrm{VC}$ was dried using anhydrous sodium sulfate and stored in a closed glass vial at $4{ }^{\circ} \mathrm{C}$ for further use.

\subsection{GC-MS Analysis}

The quantitative and qualitative analysis of the chemical composition of LPVC was carried out using gas chromatography linked to mass spectrometry (GC-MS) (Trace 1300 Gas Chromatograph, Waltham, MA, USA), equipped with a Thermo Scientific TG-5MS capillary column (length $30 \mathrm{~m}$; inner diameter $0.25 \mathrm{~mm}$; film thickness $0.25 \mu \mathrm{m}$ ) and coupled to a mass selective detector (ISQ Single Quadrupole Mass spectrometer, ionization voltage $70 \mathrm{eV})$. He was used as carrier gas with a flow rate of $1 \mathrm{~mL} / \mathrm{min}$, and the injection volume was $1 \mu \mathrm{L}$ ( $20 \mu \mathrm{L}$ of $\mathrm{VC}$ diluted with $2 \mathrm{~mL}$ of hexane). The machine temperature was programmed as follows: $1 \mathrm{~min}$ at $100{ }^{\circ} \mathrm{C}, 100$ to $260^{\circ} \mathrm{C}$ at $4{ }^{\circ} \mathrm{C} / \mathrm{min}$ and $10 \mathrm{~min}$ at $246^{\circ} \mathrm{C}$. The temperatures of the injector, transfer, source and quadrupole were $260{ }^{\circ} \mathrm{C}, 280^{\circ} \mathrm{C}$, $230^{\circ} \mathrm{C}$ and $150{ }^{\circ} \mathrm{C}$, respectively. The identification of volatile compounds was carried out by comparing their mass spectra with the reference spectra contained in the NIST database and the Adams terpenes library [43]. In addition, their retention indices (RI) were determined in relation to a series of alkanes (C9 to C24) [44].

\subsection{Antioxidant Activity}

The antioxidant activity of LPVC was evaluated as 2,2-diphenyl-1-picrylhydrazyl (DPPH) free-radical scavenging according to the method slightly modified from Blois et al., [45]. Methanolic DPPH solution $(0.06 \mathrm{mM})$ was added to LPVC at different concentrations. The 
samples were kept for $30 \mathrm{~min}$ in the dark at room temperature. Thereafter, the absorbance was measured at $517 \mathrm{~nm}$ using a spectrophotometer (UV-Visible Metashe $5200 \mathrm{HPC}$ ). The results were compared to a positive control (BHT). The percentage of DPPH radical scavenging was calculated with the following equation:

$$
\text { DPPH scavenging activity }(\%)=[(\mathrm{Ac}-\mathrm{As}) / \mathrm{Ac}] \times 100
$$

where Ac is the absorbance of the negative control (DPPH methanolic solution), and As is the absorbance of the sample.

\subsection{Antimicrobial Activity}

In order to assess the antimicrobial activity of LPVCs, three strains of resistant bacteria and a single strain of pathogenic yeast were used. The bacterial strains are named Staphylococcus aureus (CCMM B3), Pseudomonas aeruginosa (DSM 50090) and Escherichia coli (ATCC 8739). Candida albicans CCMM-L4 of vaginal origin was the only pathogenic yeast [46] used in this study. To qualitatively determine the antimicrobial activity of Lichina pygmaea VC, the disc diffusion method was used, as described previously by Nafis et al. [47]. From a fresh culture of $24-48 \mathrm{~h}$ on liquid Mueller-Hinton $(\mathrm{MH})$ for bacteria and Sabouraud (SD) for yeast, an inoculum of bacteria and yeast was prepared in sterile physiological water $(9 \% \mathrm{NaCl})$. Petri dishes containing the two culture media were inoculated using the already prepared inoculum. The excess was removed, and the Petri dishes were then dried. Sterile discs of $6 \mathrm{~mm}$ diameter were impregnated with $20 \mu \mathrm{L}$ of LPVC and placed on the surface of the agar already inoculated. Then, the Petri dishes were placed at $4{ }^{\circ} \mathrm{C}$ for $2 \mathrm{~h}$ to stop the growth of the test microorganisms and promote the diffusion of secondary metabolites of LPVC. The Petri dishes were incubated at $37^{\circ} \mathrm{C}$ for $24 \mathrm{~h}$ for bacteria and at $28^{\circ} \mathrm{C}$ for $48 \mathrm{~h}$ for yeasts. After incubation, a zone or a clear halo is present around the discs if the microbial growth is inhibited by Lichina pygmaea VC. Ciprofloxacin and fluconazol were used as positive controls. This test was performed in three repetitions. To quantitatively evaluate the antimicrobial activity of LPVC, the microdilution method was used [48]. From an overnight culture of each microorganism, microbial suspensions were prepared with the required concentration of $106 \mathrm{CFU} / \mathrm{mL}$ for bacteria and (1-2 $10^{3}$ cells $\left./ \mathrm{mL}\right)$ for yeast. Then, the dilution of $1 / 50$ th was carried out by adding $100 \mu \mathrm{L}$ of the microbial suspension in $4900 \mu \mathrm{L}$ of the culture medium suitable for each test microorganism. Serial $1 / 2$ dilutions (from $52 \mathrm{mg} / \mathrm{mL}$ to $0.21 \mathrm{mg} / \mathrm{mL}$ ) of LPVC were prepared in sterile test tubes containing Mueller-Hinton broth (MHB) for bacteria and Sabouraud broth (SDB) for yeast and Dimethylsulfoxide (DMSO) at 2\%. Then, 96-well plates were prepared by distributing in each well $100 \mu \mathrm{L}$ of the 1/50th microbial suspension and $100 \mu \mathrm{L}$ of each dilution of LPVC. The plates were then incubated at the optimum temperature for growth of the test microorganism and for the time suitable for its growth. MIC, the lowest concentration of LPVC, was the equivalent of the well that did not contain any visible microbial growth (absence of turbidity).

\section{Conclusions}

The present study showed that Lichina pygmaea volatile compounds exhibit high levels of sesquiterpenes compounds with significant antioxidant activities and moderate antimicrobial potential. The presence of himachalene derivatives could enhance the antibacterial activity, whereas the antioxidant and scavenging effects of LPVC could be related to some other substances such as $\alpha$-longipinene and caryophyllene. These interesting properties of LPVC can make it a potential candidate for pharmaceutical and cosmetic uses.

Author Contributions: Conceptualization, B.S. and V.V.; methodology, H.S., M.H., Z.B., A.R. and A.N.; software, H.S., A.N. and Z.B.; validation, B.S., A.N. and V.V.; formal analysis, Z.B. and B.S.; investigation, H.S., M.H., N.M., A.N., L.H. and Z.B.; data curation, B.S., A.N. and Z.B., writingoriginal draft preparation, Z.B. and A.N.; writing-review and editing, B.S. and V.V.; supervision, B.S. and V.V. All authors have read and agreed to the published version of the manuscript. 
Funding: This work was funded by the project VPMA3/DESRS-ANPMA-CNRST "Exploitation de la diversité spécifique et génétique pour une bioraffinerie innovante des algues marines de la côte atlantique marocaine". V.V. acknowledges FCT-Foundation for Science and Technology within the scope of UIDB/04423/2020 and UIDP/04423/2020.

Conflicts of Interest: The authors declare no conflict of interest. The funders had no role in the design of the study; in the collection, analyses, or interpretation of data; in the writing of the manuscript; nor in the decision to publish the results.

\section{References}

1. Sonina, A.V.; Androsova, V.I. Coastal Lichens. In Handbook of Halophytes; Springer International Publishing: Berlin/Heidelberg, Germany, 2020; pp. 1-22.

2. Chrismas, N.A.M.; Allen, R.; Hollingsworth, A.L.; Taylor, J.D.; Cunliffe, M. Complex photobiont diversity in the marine lichen Lichina pygmaea. J. Mar. Biol. Assoc. U. K. 2021, 101, 667-674. [CrossRef]

3. Crisp, D.J. The Ecology of Rocky Shores. JR Lewis. English Universities Press, London, 1964. xii+ 323 pp. Illus. 42s. Science 1965, 147, 601. [CrossRef]

4. Chu, F.J.; Seaward, M.R.D.; Hodgkiss, I.J. Effects of Wave Exposure and Aspect on Hong Kong Supralittoral Lichens. Lichenologist 2000, 32, 155-170. [CrossRef]

5. Zhdanov, I.; Dudoreva, T. Lichens of maritime habitats of the coast and islands of Kandalakshsky Bay of the White Sea. Bot. Zhurnal 2003, 88, 34-41.

6. Gilbert, O.L. The lichen flora of unprotected soft sea cliffs and slopes. Lichenologist 2003, 35, 245-254. [CrossRef]

7. Prieto, A.; Leal, J.A.; Bernabé, M.; Hawksworth, D.L. A polysaccharide from Lichina pygmaea and L. confinis supports the recognition of Lichinomycetes. Mycol. Res. 2008, 112, 381-388. [CrossRef]

8. Ortiz-Álvarez, R.; Rios, A.D.L.; Fernández-Mendoza, F.; Torralba-Burrial, A.; Pérez-Ortega, S. Ecological Specialization of Two Photobiont-Specific Maritime Cyanolichen Species of the Genus Lichina. PLoS ONE 2015, 10, e0132718. [CrossRef]

9. Smith, C.W. The Lichens of Great Britain and Ireland; Smith, C.W., Aptroot, A., Coppins, B.J., Fletcher, A., Gilbert, O.L., James, P.W., Wolseley, P.A., Eds.; British Lichen Society: London, UK, 2009; pp. 556-557.

10. Whitton, B.A. Ecology of Cyanobacteria II: Their Diversity in Space and Time; Springer: Berlin/Heidelberg, Germany, 2012; pp. 1-440.

11. Crawford, S. Lichens as a Potential Source of Bioactive Secondary Metabolites. In Lichen Secondary Metabolites Bioactive Properties and Pharmaceutical Potential; Springer: Berlin/Heidelberg, Germany, 2015; pp. 1-26, ISBN 978-331-913-373-7.

12. Karagöz, A.; Do, N.; Zeybek, Z.; Aslan, A. Antibacterial activity of some lichen extracts. J. Med. Plants Res. 2009, 3, 1034-1039.

13. Oksanen, I. Ecological and biotechnological aspects of lichens. Appl. Microbiol. Biotechnol. 2006, 73, 723-734. [CrossRef]

14. Kahriman, N.; Yazici, K.; Arslan, T.; Aslan, A.; Karaoglu, S.A.; Yayli, N. Chemical composition and antimicrobial activity of the essential oils from Evernia prunastri (L.) ach. and Evernia divaricata (L.) ach. Asian J. Chem. 2011, 23, 1937-1939.

15. Maqbul, M.S.; Bin Alhasel, H.M.; Majid, D.H.; Momen, T.N.; Alhazmi, H.A.M.; Al Jeddani, F.M.S.; Al Malki, R.T.W.; Khan, A.A.; Iqubal, S.M.S. Chemical Analysis (GC-FID-MS) and Antimicrobial Activity of Parmotrema perlatum Essential Oil Against Clinical Specimens. Orient. J. Chem. 2019, 35, 1695-1701. [CrossRef]

16. Leflaive, J.; Ten-Hage, L. Impairment of benthic diatom adhesion and photosynthetic activity by 2E,4E-decadienal. Res. Microbiol. 2011, 162, 982-989. [CrossRef] [PubMed]

17. Díaz, A. Volatile Compounds and Associated Genes in Cyanobacteria. Master's Thesis, Aristotle University of Thessaloniki, Thessaloníki, Greece, 2017; p. 67.

18. Wiesemeier, T.; Hay, M.; Pohnert, G. The potential role of wound-activated volatile release in the chemical defence of the brown alga Dictyota dichotoma: Blend recognition by marine herbivores. Aquat. Sci. 2007, 69, 403-412. [CrossRef]

19. Dudareva, N.; Negre, F.; Nagegowda, D.A.; Orlova, I. Plant Volatiles: Recent Advances and Future Perspectives. Crit. Rev. Plant Sci. 2006, 25, 417-440. [CrossRef]

20. El Hattab, M. Algae Essential Oils: Chemistry, Ecology, and Biological Activities. In Essential Oils-Bioactive Compounds, New Perspectives and Applications; IntechOpen: London, UK, 2020.

21. Patra, J.K.; Das, G.; Baek, K.-H. Chemical Composition and Antioxidant and Antibacterial Activities of an Essential Oil Extracted from an Edible Seaweed, Laminaria japonica L. Molecules 2015, 20, 12093-12113. [CrossRef]

22. De la Coba, F.; Aguilera, J.; Figueroa, F.L.; de Gálvez, M.V.; Herrera, E. Antioxidant activity of mycosporine-like amino acids isolated from three red macroalgae and one marine lichen. J. Appl. Phycol. 2008, 21, 161-169. [CrossRef]

23. Álvarez-Gomez, F.; Korbee, N.; Figueroa, F.L. Analysis of antioxidant capacity and bioactive compounds in marine macroalgal and lichenic extracts using different solvents and evaluation methods. Cienc. Mar. 2016, 42, 271-288. [CrossRef]

24. Lucarini, M.; Pedrielli, P.; Pedulli, G.F.; Valgimigli, L.; Gigmes, D.; Tordo, P. Bond Dissociation Energies of the N-H Bond and Rate Constants for the Reaction with Alkyl, Alkoxyl, and Peroxyl Radicals of Phenothiazines and Related Compounds. J. Am. Chem. Soc. 1999, 121, 11546-11553. [CrossRef]

25. Chen, X.; Zhang, Y.; Zu, Y.; Fu, Y.; Wang, W. Composition and biological activities of the essential oil from Schisandra chinensis obtained by solvent-free microwave extraction. LWT 2011, 44, 2047-2052. [CrossRef] 
26. Wojtunik-Kulesza, K.A.; Kasprzak, K.; Oniszczuk, T.; Oniszczuk, A. Natural Monoterpenes: Much More than Only a Scent. Chem. Biodivers. 2019, 16, e1900434. [CrossRef]

27. Zielińska-Błajet, M.; Feder-Kubis, J. Monoterpenes and Their Derivatives-Recent Development in Biological and Medical Applications. Int. J. Mol. Sci. 2020, 21, 7078. [CrossRef] [PubMed]

28. Kumar, R.; Prakash, O.; Pant, A.; Isidorov, V.A.; Mathela, C. Chemical composition, antioxidant and myorelaxant activity of essential oils of Globba sessiliflora Sims. J. Essent. Oil Res. 2012, 24, 385-391. [CrossRef]

29. Shebaby, W.; Daher, C.; El-Sibai, M.; Bodman-Smith, K.; Mansour, A.; Karam, M.C.; Mroueh, M. Antioxidant and hepatoprotective activities of the oil fractions from wild carrot (Daucus carota ssp. carota). Pharm. Biol. 2015, 53, 1285-1294. [CrossRef]

30. Kavanaugh, N.L.; Ribbeck, K. Selected Antimicrobial Essential Oils Eradicate Pseudomonas spp. and Staphylococcus aureus Biofilms. Appl. Environ. Microbiol. 2012, 78, 4057-4061. [CrossRef]

31. Breijyeh, Z.; Jubeh, B.; Karaman, R. Resistance of Gram-Negative Bacteria to Current Antibacterial Agents and Approaches to Resolve It. Molecules 2020, 25, 1340. [CrossRef] [PubMed]

32. Costa-De-Oliveira, S.; Rodrigues, A.G. Candida albicans Antifungal Resistance and Tolerance in Bloodstream Infections: The Triad Yeast-Host-Antifungal. Microorganisms 2020, 8, 154. [CrossRef]

33. Bakus, G.J.; Targett, N.M.; Schulte, B. Chemical ecology of marine organisms: An overview. J. Chem. Ecol. 1986, 12, 951-987. [CrossRef] [PubMed]

34. Manojlovic, N.; Vasiljević, P.; Mašković, P.; Juskovic, M.; Bogdanovic-Dusanovic, G. Chemical Composition, Antioxidant, and Antimicrobial Activities of Lichen Umbilicaria cylindrica (L.) Delise (Umbilicariaceae). Evidence-Based Complement. Altern. Med. 2011, 2012, 452431. [CrossRef]

35. Aoussar, N.; Laasri, F.E.; Bourhia, M.; Manoljovic, N.; Mhand, R.A.; Rhallabi, N.; Ullah, R.; Shahat, A.A.; Noman, O.M.; Nasr, F.A.; et al. Phytochemical Analysis, Cytotoxic, Antioxidant, and Antibacterial Activities of Lichens. Evidence-Based Complement. Altern. Med. 2020, 2020, 8104538. [CrossRef]

36. Chaudhary, A.; Sood, S.; Das, P.; Kaur, P.; Mahajan, I.; Gulati, A.; Singh, B. Synthesis of novel antimicrobial aryl himachalene derivatives from naturally occurring himachalenes. EXCLI J. 2014, 13, 1216. [CrossRef]

37. Derwich, E.; Benziane, Z.; Boukir, A. Chemical composition and In Vitro antibacterial activity of the essential oil of Cedrus atlantica. Int. J. Agric. Biol. 2010, 12, 381-385.

38. Elias, A.; Shebaby, W.; Nehmeh, B.; Faour, W.; Bassil, B.; El Hakim, J.; Iskandar, R.; Dib-Jalbout, N.; Mroueh, M.; Daher, C.; et al. In Vitro and In Vivo Evaluation of the Anticancer and Anti-inflammatory Activities of 2-Himachelen-7-ol isolated from Cedrus Libani. Sci. Rep. 2019, 9, 12855. [CrossRef]

39. Sosa-Moguel, O.; Pino, J.A.; Ayora-Talavera, G.; Sauri-Duch, E.; Cuevas-Glory, L. Biological activities of volatile extracts from two varieties of Habanero pepper (Capsicum chinense Jacq.). Int. J. Food Prop. 2017, 20, S3042-S3051. [CrossRef]

40. Asdadi, A.; Hamdouch, A.; Oukacha, A.; Moutaj, R.; Gharby, S.; Harhar, H.; El Hadek, M.; Chebli, B.; Hassani, L.I. Study on chemical analysis, antioxidant and in vitro antifungal activities of essential oil from wild Vitex agnus-castus L. seeds growing in area of Argan Tree of Morocco against clinical strains of Candida responsible for nosocomial infections. J. Mycol. Med. 2015, 25, e118-e127. [CrossRef]

41. Ghaffari, T.; Kafil, H.S.; Asnaashari, S.; Farajnia, S.; Delazar, A.; Baek, S.C.; Hamishehkar, H.; Kim, K.H. Chemical Composition and Antimicrobial Activity of Essential Oils from the Aerial Parts of Pinus eldarica Grown in Northwestern Iran. Molecules 2019, 24, 3203. [CrossRef]

42. Nafis, A.; Kasrati, A.; Jamali, C.A.; Samri, S.E.; Mezrioui, N.; Abbad, A.; Hassani, L. Antioxidative Effect and First Evidence of Synergistic Antimicrobial Effects of Ficus carica (L.) Leaf Essential Oil with Conventional Antibiotics. J. Essent. Oil Bear. Plants 2019, 22, 1289-1298. [CrossRef]

43. Adams, R.P. Identification of Essential Oil Components by Gas Chromatography/Mass Spectrometry, 4th ed.; Allured Publishing Corporation: Carol Stream, IL, USA, 2007.

44. Nafis, A.; Ouedrhiri, W.; Iriti, M.; Mezrioui, N.; Marraiki, N.; Elgorban, A.M.; Syed, A.; Hassani, L. Chemical composition and synergistic effect of three Moroccan lavender EOs with ciprofloxacin against foodborne bacteria: A promising approach to modulate antimicrobial resistance. Lett. Appl. Microbiol. 2021, 72, 698-705. [CrossRef] [PubMed]

45. Blois, M.S. Antioxidant Determinations by the Use of a Stable Free Radical. Nature 1958, 181, 1199-1200. [CrossRef]

46. Nafis, A.; Kasrati, A.; Jamali, C.A.; Mezrioui, N.; Setzer, W.; Abbad, A.; Hassani, L. Antioxidant activity and evidence for synergism of Cannabis sativa (L.) essential oil with antimicrobial standards. Ind. Crop. Prod. 2019, 137, 396-400. [CrossRef]

47. Nafis, A.; Oubaha, B.; Elhidar, N.; Ortlieb, N.; Kulik, A.; Niedermeyer, T.; Hassani, L.; Barakate, M. Novel Production of Two New Nonpolyenic Antifungal Macrolide Derivatives by Streptomyces Z26 Isolated from Moroccan Rhizospheric Soil. Online J. Biol. Sci. 2018, 18, 176-185. [CrossRef]

48. Nafis, A.; Hassani, L.; Marraiki, N.; Al-Rashed, S.; Elgorban, A.M.; Syed, A.; Iriti, M. Antimicrobial and synergistic effect of Moroccan native Argania spinosa essential oil for modulating of antibiotics resistance. Nat. Prod. Res. 2020, 35, 6078-6082. [CrossRef] [PubMed] 